\title{
Regulated interactions between partner and non-partner sensors and response regulators that control glycopeptide resistance gene expression in enterococci
}

\author{
Michel Arthur, $†$ Florence Depardieu and Patrice Courvalin
}

Unité des Agents

Antibactériens, Institut

Pasteur, 28 rue du Dr Roux,

75724 Paris Cedex 15, France
Author for correspondence: Florence Depardieu. Tel: +331456883 21. Fax: + 33145688319. e-mail: fdepard $a$ pasteur.fr

\begin{abstract}
Transcription of the vanA and vanB glycopeptide resistance gene clusters is regulated by the VanRS and $\operatorname{Van}_{\mathrm{B}} \mathrm{S}_{\mathrm{B}}$ two-component regulatory systems, respectively. Histidine to glutamine substitutions were introduced at positions

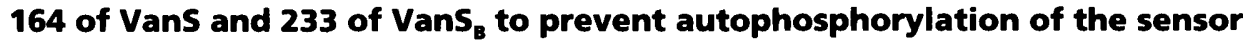
kinases and transfer of the phosphate groups to the $\operatorname{VanR}$ and $\operatorname{Van}_{\mathrm{B}}$ response regulators. VanSH ${ }_{164} Q$ and $\operatorname{VanS}_{B} H_{233} Q$ abolished activation of $\operatorname{VanR}$ and $\operatorname{VanR}_{\mathrm{B}}$ by host kinases. The phosphatase activity of $\mathrm{VanS}_{\mathrm{B}} \mathrm{H}_{233} \mathrm{Q}$ was negatively modulated by vancomycin whereas $\mathrm{VanSH}_{164} \mathrm{Q}$ prevented transcription of the resistance genes under all growth conditions. Cross-talk was detected between Van $_{B}$ and VanS in a van $S_{B}$ null mutant. VanR is required for activation of promoters $P_{R}$ and $P_{H}$ allowing transcription of the regulatory (vanRS) and resistance (vanHAXYZ) genes, respectively. Under non-inducing conditions, activation of VanR by cross-talk was blocked by the presence of a multicopy plasmid carrying $\boldsymbol{P}_{H^{-}}$. Presence of the high-affinity VanR-binding sites of the regulatory region of $P_{H}$ on the multicopy vector probably sequestered VanR, thereby preventing autoactivation of the $P_{R}$ promoter. Under such circumstances, stimulation of the host kinase by glycopeptides or moenomycin was required for expression of the resistance genes.
\end{abstract}

Keywords: glycopeptide resistance, peptidoglycan, two-component regulatory system, cross-talk, enterococci

\section{INTRODUCTION}

Acquired resistance to the glycopeptide antibiotics vancomycin and teicoplanin in enterococci is due to production of peptidoglycan precursors ending in the depsipeptide D-alanyl-D-lactate (D-Ala-D-Lac) instead of the dipeptide D-Ala-D-Ala (Arthur et al., 1996b; Walsh et al., 1996). Resistance by this mechanism is mediated by two related gene clusters, van $A$ and $v a n B$, that encode a dehydrogenase and a ligase for synthesis of $D$ Ala-D-Lac and two DD-peptidases for elimination of peptidoglycan precursors ending in D-Ala (Fig. 1) (Bugg et al., 1991; Arthur et al., 1998). Transcription of the van $A$ and vanB clusters is regulated by the VanRS and $\operatorname{VanR}_{\mathrm{B}} \mathrm{S}_{\mathrm{B}}$ two-component regulatory systems (Arthur et al., 1992; Evers \& Courvalin, 1996). Phosphorylation of

\footnotetext{
†Present address: Biochimie Structurale et Cellulaire, CNRS EP 1088, Université Paris-Sud, 91405 Orsay Cedex, France.
}

the VanR response regulator enhances the affinity of the protein for the regulatory regions of the $P_{R}$ and $P_{H}$ promoters and allows transcription of the regulatory (vanRS) and resistance (vanHAXYZ) genes, respectively (Holman et al., 1994; Arthur et al., 1997). Similarly, $V_{\text {anR }}$ is required for activation of the $P_{R B}$ and $P_{Y B}$ promoters located upstream from the regulatory and resistance genes of the $v a n B$ cluster (Evers \& Courvalin, 1996; Silva et al., 1998). The level of phosphorylation of VanR and $\operatorname{VanR}_{B}$ is modulated by the kinase and phosphatase activities of the $\operatorname{VanS}$ and $\operatorname{VanS}_{\mathrm{B}}$ sensors, respectively (Wright et al., 1993; Arthur et al., 1997; Baptista et al., 1997). The response regulators can also be activated by kinases encoded by the host chromosome in the absence of their partner sensors (Arthur et al., 1997; Silva et al., 1998; Baptista et al., 1999).

Activation of the $P_{R}$ and $P_{H}$ promoters by VanR is inducible by vancomycin, teicoplanin and moenomycin in wild VanA-type strains and constitutive in vanS null 
vanA

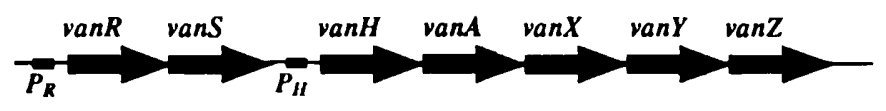

$\operatorname{vanB}$

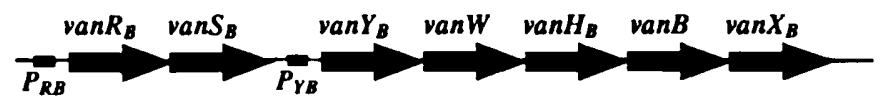

Regulation

D-Ala-D-Lac synthesis

Response regulator

VanR $\operatorname{VanR}_{B} 33 \%$

D-Lac dehydrogenase

VanH $\mathrm{VanH}_{\mathrm{B}} \quad 67 \%$

D-Ala:D-Lac ligase

Kinase

VanS $\operatorname{VanS}_{\mathrm{B}} \quad 19 \%$
VanA VanB $76 \%$
Hydrolysis of precursors ending in D-Ala

D,D-dipeptidase

$\operatorname{Van} X \quad \operatorname{Van}_{\mathrm{B}} \quad 71 \%$

D,D-carboxypeptidase

$\operatorname{Van} Y \operatorname{Van}_{\mathrm{B}} \quad 30 \%$
Fig. 1. Map of the van $A$ and $\operatorname{van} B$ gene clusters. The percentage of identical amino acids between homologous proteins is indicated. Each cluster contains two promoters for transcription of the regulatory $\left(P_{R}\right.$ for van $R S$ and $P_{R B}$ for van $\left.R_{B} S_{B}\right)$ and resistance $\left(P_{H}\right.$ for vanHAXYZ and $P_{Y B}$ for van $Y_{B} W H_{B} B X_{B}$ ) genes (Evers \& Courvalin, 1996; Holman et al., 1994; Arthur et al., 1997; Silva et al., 1998).

Table 1. Characteristics of $\operatorname{VanR}$ and $\operatorname{Van}_{\mathrm{B}}$ activation by various kinases

\begin{tabular}{|c|c|c|c|}
\hline Sensor & Phenotype & $\begin{array}{l}\text { Putative signal for the } \\
\text { sensor }\end{array}$ & Reference \\
\hline \multicolumn{4}{|c|}{ Activation of VanR by: } \\
\hline VanS & $\begin{array}{l}\text { Inducible by vancomycin, teicoplanin and } \\
\text { moenomycin }\end{array}$ & Accumulation of lipid II & $\begin{array}{l}\text { Handwerger \& Kolokathis } \\
(1990)\end{array}$ \\
\hline $\operatorname{VanSH}_{164} \mathrm{Q}$ & $\begin{array}{l}\text { Not inducible since the sensor acts as a phosphatase } \\
\text { under all conditions }\end{array}$ & Not applicable & This work \\
\hline Host kinase & $\begin{array}{l}\text { Constitutive or inducible by vancomycin, } \\
\text { teicoplanin and moenomycin depending upon the } \\
\text { relative copy numbers of } P_{H} \text { and } P_{R}\end{array}$ & Accumulation of lipid II & $\begin{array}{l}\text { This work; Arthur et al. } \\
\text { (1997) }\end{array}$ \\
\hline \multicolumn{4}{|c|}{ Activation of $\operatorname{Van}_{B}$ by: } \\
\hline $\operatorname{VanS}_{\mathrm{B}}$ & Inducible by vancomycin & Interaction with the drug & Baptista et al. (1996) \\
\hline $\operatorname{VanS}_{\mathrm{B}} \mathrm{H}_{233} \mathrm{Q}$ & Inducible by vancomycin (loss of kinase activity) & Interaction with the drug & This work \\
\hline $\operatorname{VanS}_{B} A_{167} S$ & $\begin{array}{l}\text { Inducible by vancomycin and teicoplanin (extension } \\
\text { of specificity) }\end{array}$ & Interaction with the drugs & Baptista et al. (1999) \\
\hline $\operatorname{VanS}_{\mathrm{B}} \mathrm{T}_{2: 37} \mathrm{M}$ & Constitutive (loss of phosphatase activity) & Not applicable & Baptista et al. (1999) \\
\hline Host kinase & $\begin{array}{l}\text { Inducible by vancomycin, teicoplanin and } \\
\text { moenomycin }\end{array}$ & Accumulation of lipid II & Baptista et al. (1999) \\
\hline
\end{tabular}

mutants (Arthur et al., 1997) (Table 1). Glycopeptides and moenomycin inhibit the transglycosylation reaction by different mechanisms and are structurally unrelated, indicating that induction by these antibiotics is unlikely to involve direct interaction of the VanS sensor with the drugs (Handwerger \& Kolokathis, 1990). Since moenomycin and glycopeptides block incorporation of lipid intermediate II into nascent peptidoglycan, accumulation of this precursor may be the signalling stimulus for VanS (Baptista et al., 1996).

Expression of the vanB cluster is inducible by vancomycin only in wild VanB-type strains and inducible by vancomycin, teicoplanin and moenomycin in $v a n S_{B}$ null mutants (Table 1) (Evers \& Courvalin, 1996; Baptista et al., 1999). Activation of $\operatorname{VanR}_{\mathrm{B}}$ by cross-talk leads to clonal variation under non-inducing conditions (Baptista et al., 1999). Amino acid substitutions in the $\mathrm{N}$ terminal sensing domain of $\mathrm{VanS}_{\mathrm{B}}$ allow induction by teicoplanin but not by moenomycin (Baptista et al.,
1997; Baptista et al., 1999). Stimulation of $\mathrm{VanS}_{\mathrm{B}}$ may involve direct interaction with the antibiotic since this would account for the fact that antibiotics with the same mode of action but different structures are not all inducers (Baptista et al., 1999). The $\mathrm{T}_{237} \mathrm{M}$ substitution in $V_{a n S}$ impairs the phosphatase activity of the sensor and leads to constitutive expression of the resistance genes (Baptista et al., 1999).

In this report, site-directed mutagenesis was used to introduce glutamine instead of histidine residues at the putative autophosphorylation site of $\operatorname{VanS}\left(\mathrm{H}_{164}\right)$ and $\operatorname{VanS}_{\mathrm{B}}\left(\mathrm{H}_{233}\right)$. Based on previous analyses, the resulting proteins, $\mathrm{VanSH}_{164} \mathrm{Q}$ and $\mathrm{VanS}_{\mathrm{B}} \mathrm{H}_{233} \mathrm{Q}$, were expected to be unable to activate the response regulators by phosphorylation but to retain phosphatase activity (Haldimann et al., 1997; Hsing \& Silhavy, 1997). The in vivo activity of $\mathrm{VanSH}_{164} \mathrm{Q}$ and $\mathrm{VanS}_{\mathrm{B}} \mathrm{H}_{233} \mathrm{Q}$ was determined based on comparison of the regulation of the vanX and $\operatorname{van} X_{B}$ DD-dipeptidase genes in strains har- 
bouring various alleles of vanS and $v a n S_{B}$ (Table 1). The role of inducible expression of the $\operatorname{van} R$ and $v a n S$ genes in the regulation of the vanA gene cluster was also investigated.

\section{METHODS}

Strains and growth conditions. The origin and properties of the Enterococcus faecalis strains and plasmids used are described in Table 2. E. faecalis $\mathrm{JH} 2-2$ and $\mathrm{BM} 4110$ are derivatives of strain $\mathrm{JH} 2$, resistant to fusidic acid and rifampicin or to streptomycin, respectively. Strains were grown in brain heart infusion (BHI) broth and agar (Difco) at $37^{\circ} \mathrm{C}$. Spectinomycin $\left(60 \mu \mathrm{g} \mathrm{ml}^{-1}\right)$, gentamicin $\left(32 \mu \mathrm{g} \mathrm{ml} \mathrm{m}^{-1}\right)$ and erythromycin $\left(10 \mu \mathrm{g} \mathrm{ml}^{-1}\right)$ were added to the media to prevent loss of plasmids derived from pAT78, pAT392 and pIP836, respectively.

Plasmid construction. Plasmid DNA isolation, digestion with restriction endonucleases (Boehringer Mannheim), amplification of DNA by PCR with Pfu DNA polymerase (Strata-

Table 2. Characteristics and origin of the plasmids and strains used

\begin{tabular}{|c|c|c|}
\hline Plasmid or strain & Origin and relevant characteristics ${ }^{*}$ & Source or reference \\
\hline \multicolumn{3}{|l|}{ Plasmids } \\
\hline pAT29 & Shuttle vector $\left(\mathrm{Sp}^{\mathrm{r}}\right)$ & Trieu-Cuot et al. (1990) \\
\hline pAT78 & $\begin{array}{l}\text { Derivative of pAT29 carrying the cat reporter } \\
\text { gene }\end{array}$ & Arthur et al. (1992) \\
\hline pAT392 & $\begin{array}{l}\text { Derivative of pAT29 carrying the } P_{2} \text { promoter } \\
\text { and the } a a c\left(6^{\prime}\right)-a p h\left(2^{\prime \prime}\right) \text { gene }\left(\mathrm{Gm}^{\mathrm{r}}\right)\end{array}$ & Arthur et al. (1994) \\
\hline pAT90 & $\begin{array}{l}\text { Derivative of pAT78 harbouring a } P_{H}-c a t \\
\text { transcriptional fusion }\end{array}$ & Arthur et al. (1992) \\
\hline pAT418 & $\begin{array}{l}\text { Derivative of pAT78 harbouring a } P_{R}-c a t \\
\text { transcriptional fusion }\end{array}$ & Arthur et al. (1997) \\
\hline pAT626 & Replacement of the $P_{2}$ promoter of pAT392 by $P_{R}$ & This work \\
\hline pAT627 & Replacement of the $P_{2}$ promoter of pAT392 by $P_{H}$ & This work \\
\hline pAT628 & $\begin{array}{l}\text { vanS gene cloned under the control of the } P_{2} \\
\text { promoter of pAT392 }\end{array}$ & This work \\
\hline pAT629 & $\begin{array}{l}\text { vanSH }{ }_{164} \mathrm{Q} \text { gene cloned under the control of the } \\
P_{2} \text { promoter of pAT392 }\end{array}$ & This work \\
\hline pAT630 & $\begin{array}{l}\operatorname{van} S_{R} \mathrm{H}_{233} \mathrm{Q} \text { gene cloned under the control of the } \\
P_{2} \text { promoter of pAT392 }\end{array}$ & This work \\
\hline pAT631 & $\begin{array}{l}\text { van } S_{B} \text { gene cloned under the control of the } P_{2} \\
\text { promoter of pAT392 }\end{array}$ & This work \\
\hline pIP836 & $\begin{array}{l}\text { Self-transferable plasmid harbouring a wild-type } \\
\text { vanB gene cluster }\left(\mathrm{Em}^{r}\right)\end{array}$ & Baptista et al. (1999) \\
\hline pIP842 & $\begin{array}{l}\text { Derivative of pIP836 harbouring the } \operatorname{van} S_{R} Y_{12} \text { ter } \\
\text { mutation }\end{array}$ & Baptista et al. (1999) \\
\hline \multicolumn{3}{|l|}{ E. faecalis strains } \\
\hline $\mathrm{JH} 2-2$ & Fus $^{r}$ Rif $^{r}$ derivative of $\mathrm{JH} 2$ & Jacob \& Hobbs (1974) \\
\hline BM4110 & Str ${ }^{r}$ derivative of $\mathrm{JH} 2$ & $\begin{array}{l}\text { Courvalin \& Carlier } \\
\text { (1986) }\end{array}$ \\
\hline BM4311 & $\begin{array}{l}P_{R} v a n R S \text { inserted into the chromosome of } \\
\mathrm{JH} 2-2\end{array}$ & Arthur et al. (1992) \\
\hline BM4312 & $P_{2}$ vanR inserted into the chromosome of $\mathrm{JH} 2-2$ & Arthur et al. (1997) \\
\hline BM4332 & $\begin{array}{l}P_{R} \text { vanRP } P_{H} v a n H A X c a t \text { gene cluster inserted into } \\
\text { the chromosome of } \mathrm{JH} 2-2\end{array}$ & Arthur et al. (1997) \\
\hline BM4375 & $P_{R} v a n R$ inserted into the chromosome of $\mathrm{JH} 2-2$ & This work \\
\hline BM4396 & pIP836 $\left(\right.$ vanS $\left._{B}\right)$ in BM4110 & Baptista et al. (1999) \\
\hline BM4399 & pIP842(vanS $S_{B} Y_{12}$ ter $)$ in BM4110 & Baptista et al. (1999) \\
\hline BM4406 & $\begin{array}{l}\text { pIP842 }\left(\text { vanS }_{B} \mathrm{Y}_{12} \text { ter }\right) \text { and } \mathrm{pAT} 630\left(P_{2} \operatorname{vanS}_{B} \mathrm{H}_{233} \mathrm{Q}\right) \\
\text { in BM4110 }\end{array}$ & This work \\
\hline BM4407 & $\begin{array}{l}\text { pIP842 }\left(\text { vanS }_{B} \mathrm{Y}_{12} \text { ter }\right) \text { and pAT628 }\left(P_{2} \text { vanS }\right) \text { in } \\
\text { BM4110 }\end{array}$ & This work \\
\hline BM4408 & $\begin{array}{l}\left.\text { pIP842(van } S_{B} Y_{12} \text { ter }\right) \text { and } \mathrm{pAT} 629\left(P_{2} \operatorname{vanSH}_{164} \mathrm{Q}\right) \\
\text { in BM4110 }\end{array}$ & This work \\
\hline
\end{tabular}

"Em, erythromycin; Fus, fusidic acid; Gm, gentamicin; Rif, rifampicin; Sp, spectinomycin; Str, streptomycin; ter, termination. 
gene), ligation of DNA fragments with T4 DNA ligase (Pharmacia Biotech), Southern hybridization, nucleotide sequencing with T7 DNA polymerase (Pharmacia) and transformation of Escherichia coli JM83 with recombinant plasmids were performed by standard methods (Ausubel et al., 1987).

For the construction of pAT628( $P_{2}$ vanS $)$, the vanS gene of pAT80 (P elanRSP $_{n} H A X$ cat) (Arthur et al., 1992) was amplified with oligodeoxyribonucleotides NA1 and CA1, digested with $S a C I$ and $X b a I$, and cloned under the control of the $P_{2}$ promoter of the shuttle vector pAT392. Primer NA1 $\left(5^{\prime}-\right.$ GCACGAGCTCTTGAAAGGAGACAGGAGCATGGTTATAAAATTGAAA) contained a Sacl site (italicized), a ribosome-binding site (RBS; underlined) and 18 bases of van $S$ including the ATG translation initiation codon (underlined). Primer CAl (5'-TAACTCTAGATTAGGACCTCCTTTTAT) comprised a recognition site for $\mathrm{Xbal}$ (italicized) and 17 bases of the $3^{\prime}$ end of vanS including the stop codon (underlined).

Plasmid pAT629 $\left(P_{2}\right.$ vanSH $\left._{16.4} \mathrm{Q}\right)$ was obtained by cloning the van $\mathrm{SH}_{164} \mathrm{Q}$ gene under the control of the $P_{2}$ promoter of pAT392. The vanSH ${ }_{164} \mathrm{Q}$ gene was constructed by two sequential amplifications leading to the replacement of the CAC codon specifying His at position 164 by a CAG glutamine codon. In the first step, two overlapping portions of vanS were independently amplified using primers NA1 plus N164 and C164 plus CA1. Primer N164 (5'-CTGCGCCAAGTACATAAC) was complementary to the vans coding strand upstream from codon 164 and contained a CTG triplet (underlined) that was complementary to a CAG glutamine codon for replacement of the CAC histidine codon at position 164. Primer 164 (5'-GTTATGTACTTGGCGCAGGATATTAAAACG(iCCCT) contained 18 bases complementary to the sequence of primer N164 (underlined) and 17 bases of vanS downstream from codon 164. For the second step, the amplicons obtained with NAI plus N164 and C164 plus CA1 were purified (Microspin S-400 HR; Pharmacia), mixed, denatured $\left(10 \mathrm{~min}, 95^{\circ} \mathrm{C}\right)$ and annealed $\left(30 \mathrm{~min}, 50^{\circ} \mathrm{C}\right)$. Primers NA1 and CAl were added and the $v a n \mathrm{SH}_{164} \mathrm{Q}$ gene was amplified. The amplicon was digested with $\mathrm{SaCl}$ and $\mathrm{XbaI}$ and cloned into pAT392 $\left(P_{2}\right)$ digested with the same enzymes generating $\mathrm{pAT} 629\left(P_{2} v^{2}\right.$ anS $\left.\mathrm{H}_{164} \mathrm{Q}\right)$.

For the construction of pAT630 $\left(P_{2} \operatorname{vanS}_{B} \mathrm{H}_{233} \mathrm{Q}\right)$, the van $S_{B} \mathrm{H}_{2333} \mathrm{Q}$ gene was obtained by two sequential amplifications and cloned under the control of the $P_{2}$ promoter of pAT392 using $S a c$ I and $X b a I$ as described for pAT629( $\left.P_{2} u^{\prime} a n S H_{164} Q\right)$. Briefly, the 5 ' portion of van $S_{B}$ was amplified using primers NB1 and N233. NB1 $\left(5^{\prime}\right.$ GCACGAGCTCTTGAAAGGAGACAGGAGCATGGAAAGAAAAGGGAT) contained a $S a c$ lite (italicized), an RBS

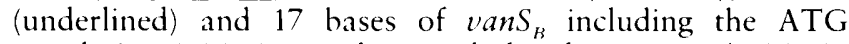
translation initiation codon (underlined). N233 (5'-CTGAGAGGCTGCCGCAAA) was complementary to codons 228233 of $v^{2} a n S_{B}$ with a $G$ to $C$ base substitution (underlined) for replacement of $\mathrm{CAC}$ (His) by CAG $(\mathrm{Gln})$ at codon 233 . The 3 ' portion of ${ }^{\prime} a n S_{t 3}$ was amplified with primers C233 and CB1. Primer C233 (5'-TTTGCGGCAGCCTCTCAGGAGTTAAAAAC(iCCCAT) contained 18 bases complementary to the sequence of primer N23.3 (underlined) and 17 bases of $z^{\prime} a n S_{n}$ downstream from codon 233. Primer CB1 $5^{\prime}$ AGTGTCTAGATTATAGTGTTGATGTGG) comprised a recognition site for $X b a l$ (italicized) and 17 bases of the $3^{\prime}$ extremity of $v a n S_{B}$ including the stop codon (underlined). The amplicons obtained with NB1 plus N233 and C233 plus CB1 were purified, annealed and the $\operatorname{vanS}_{H} \mathrm{H}_{2: 33} \mathrm{Q}$ gene was amplified with primers NB1 and CB1. For construction of pAT631 $\left(P_{2}\right.$ van $\left.S_{R}\right)$, van $_{B}$ was amplified using primers NB11 and CB1, the amplicon was digested with $S a c I$ plus $X b a I$ and cloned into pAT392 digested with the same enzymes. Primers NB11 (5'-GCACGAGCTCTTGAAAGGAGACAGGAGCATGCATCACCATCACCATCACGAAAGAAAAGGGATTTT) contained a Sacl site (italicized), an ATG translation initiation codon preceded by an RBS (underlined), $6 \mathrm{His}$ codons (italicized) and 17 bases of vanS $S_{B}$ downstream from the initiation codon (underlined).

Plasmid pAT626(P $\left.P_{r}\right)$ was constructed by replacing the EcoRI-SacI fragment of pAT392 carrying the $P_{2}$ promoter by an EcoRI-Sacl fragment harbouring the $P_{R}$ promoter. The latter fragment was obtained by amplification of the $P_{R}$ promoter of $\mathrm{pAT} 80\left(P_{R}\right.$ vanRSP $\left.{ }_{H} H A X c a t\right)$ using primers R1 and R2 as described previously (Arthur et al., 1997).

Plasmid pAT627 $\left(P_{H}\right)$ was constructed in two steps. The $P_{H}$ promoter was amplified by PCR using DNA of pAT87 $\left(P_{H}\right.$ vanHAXcat) (Arthur et al., 1992) as a template and oligodeoxyribonucleotides $\mathrm{H} 1$ and 'sequencing 17-mer' (Amersham) as primers. Primer H1 (5'-ATGAGAGCTCACAGTAATGCCGATGTTATT) contained a Sacl site (italicized) and 20 bases complementary to codons 2-8 of the vanH gene. The 'sequencing 17 -mer' primer was complementary to the sequence of the vector upstream from the EcoRI site. The amplicon was digested with EcoRI plus SacI and cloned into pAT29 digested with the same enzymes. In the second step, the Sacl-SphI fragment of pAT392 carrying the $a a c\left(6^{\prime}\right)-a p h\left(2^{\prime \prime}\right)$ gentamicin resistance gene was cloned downstream from $P_{H}$. The nucleotide sequence of the inserts obtained by PCR was redetermined.

Strain construction. E. faecalis BM4375 was obtained by inserting a copy of the $v a n R$ gene under the control of the $P_{R}$ promoter into the chromosome of $\mathrm{JH} 2-2$ using the suicide vector pAT113 (Trieu-Cuot et al., 1991). Integrative plasmid pAT615 $\left(P_{R} v a n R\right)$ (Arthur et al., 1997) was introduced into $E$. faecalis JH2-2/pAT $145\left(\mathrm{Km}^{\mathrm{r}} \mathrm{Int}-\mathrm{Tn} n\right)$ by electrotransformation and clones resulting from chromosomal integration of pAT615 mediated by the Int-Tn integrase were selected on agar containing erythromycin $\left(10 \mu \mathrm{g} \mathrm{ml}^{-1}\right)$. Spontaneous loss of pAT145(K $\left.{ }^{r} \operatorname{Int}-\mathrm{Tn}\right)$ was obtained by subculturing transformants for approximately 30 generations in antibiotic-free medium. Total DNA of a clone, designated BM4375( $P_{n}$ vanR), was digested with EcoRI and HindIII and analysed by Southern hybridization using pAT615-labelled DNA as a probe. The data obtained (not shown) indicated the presence of a single chromosomal copy of pAT615( $\left.P_{R} v a n R\right)$.

For construction of BM4406, BM4407 and BM4408, plasmids pAT630 $\left(P_{2} v_{\text {van }} \mathrm{H}_{233} \mathrm{Q} \mathrm{Gm}^{\mathrm{r}}\right), \operatorname{pAT} 628\left(P_{2}\right.$ vanS $\left.\mathrm{Gm}^{\mathrm{r}}\right)$ and pAT629 $\left(P_{2}\right.$ vanSH $\left.{ }_{164} \mathrm{Q} \mathrm{Gm}^{r}\right)$, respectively, were introduced into E. faecalis BM4110 by electroporation (Cruz-Rodz \& Gilmore, 1990) and transformants were selected on agar containing gentamicin $\left(32 \mu \mathrm{g} \mathrm{ml}^{-1}\right)$. Plasmid pIP842 (van $S_{B} \mathrm{Y}_{12}$ ter $\left.\mathrm{Em}^{r}\right)$ was introduced into the resulting transformants by filter mating using BM4399 as a donor. Transconjugants were selected on agar containing gentamicin $\left(32 \mu \mathrm{g} \mathrm{ml}^{-1}\right)$ and erythromycin $\left(10 \mu \mathrm{g} \mathrm{ml}^{-1}\right)$.

Enzyme assays. For preparation of cytoplasmic extracts, $8 \mathrm{ml}$ of an overnight culture were added to $100 \mathrm{ml}$ broth containing vancomycin, teicoplanin or moenomycin at various concentrations and bacteria were grown until the optical density at $600 \mathrm{~nm}$ reached $0 \cdot 7$. The cells were harvested by centrifugation, washed in $0 \cdot 1 \mathrm{M}$ phosphate buffer $\mathrm{pH} 7 \cdot 0$, resuspended in the same buffer, treated with lysozyme and lysed 
by sonication (Arthur et al., 1996a). The lysate was centrifuged for $45 \mathrm{~min}$ at $100000 \mathrm{~g}$ and the supernatant was assayed for $\operatorname{VanX}$ and $\operatorname{Van}_{\mathrm{B}}$ DD-dipeptidase activity using D-Ala-D-Ala as the substrate and D-amino acid oxidase coupled to peroxidase for the indicator reactions (Arthur et al., 1996a). The supernatant was also assayed for chloramphenicol acetyltransferase activity as previously described (Arthur et al., 1992).

\section{RESULTS AND DISCUSSION}

\section{Phosphatase activity of Van $\mathrm{S}_{8} \mathrm{H}_{233} \mathrm{Q}$}

Determination of $\operatorname{Van} \mathrm{X}_{\mathrm{B}}$ DD-dipeptidase activity indicated that expression of the resistance genes was inducible by vancomycin, teicoplanin and moenomycin in BM4399, which contained a translation stop at codon 12 of $v a n S_{B}$ (Table 3). Thus, $\operatorname{VanR}_{\mathrm{B}}$ was activated by a heterologous kinase as previously described for van $S_{B}$ null mutants (Table 1; Baptista et al., 1999). In contrast, expression of $v a n X_{B}$ was inducible by vancomycin only in BM4396 and BM4406, which produced $\mathrm{VanS}_{\mathrm{B}}$ and $\mathrm{VanS}_{\mathbf{B}} \mathrm{H}_{233} \mathrm{Q}$, respectively (Table 3 ). The wild-type sensor acted as a phosphatase in the absence of vancomycin since production of $\mathrm{VanS}_{\mathrm{B}}$ reduced expression of $\operatorname{van} X_{B}$ under non-inducing conditions and prevented induction by teicoplanin and moenomycin. $\mathrm{VanS}_{\mathrm{B}}$ may act as a kinase in the presence of vancomycin although the increase in $\operatorname{van} X_{B}$ expression associated with production of $V_{a n S}$ was small. $\operatorname{VanS}_{\mathrm{B}} \mathrm{H}_{233} \mathrm{Q}$ had phosphatase activity since it also prevented expression of $\operatorname{van} X_{B}$ in media containing teicoplanin, moenomycin or no antibiotic. Expression of $v a n X_{B}$ was inducible by vancomycin, revealing that the phosphatase activity of VanS ${ }_{\mathrm{B}} \mathrm{H}_{233} \mathrm{Q}$ was inhibited by this antibiotic, allowing activation of $\operatorname{VanR}_{B}$ by the heterologous kinase. Thus, the phosphatase activity of $\operatorname{VanS}_{\mathrm{B}}$ was regulated independently from the reaction of autophosphorylation at the histidine residue position 233. Fig. 2 presents a working model for the phosphatase and kinase activities of $\operatorname{VanS}_{\mathrm{B}}$ and $\operatorname{VanS}_{\mathrm{B}} \mathrm{H}_{233} \mathrm{Q}$.

\section{Phosphatase activity of $\mathrm{VanSH}_{164} \mathrm{Q}$}

E. faecalis $\mathrm{BM} 4332\left(P_{R}\right.$ van $R P_{H}$ van $\left.H A X\right)$ harbours a chromosomal copy of $v a n R$ under the control of the $P_{R}$ promoter and of the vanHAX operon under the control of the $P_{H}$ promoter (Fig. $2 \mathrm{~d}$ ). The $P_{R}$ vanR $P_{H}$ vanHAX cluster was generated by a deletion internal to vanS (Arthur et al., 1997). Expression of vanX was constitutive in $\mathrm{BM} 4332\left(P_{R}\right.$ vanR $P_{H}$ van $\left.H A X\right)$, indicating that VanR was activated by a heterologous kinase in the absence of VanS (Arthur et al., 1997). High-level expression of $v a n X$ did not require stimulation of the heterologous kinase by glycopeptides. Likewise, insertional inactivation of $\operatorname{vanS}$ in the $\operatorname{van} A$ gene cluster carried by a natural plasmid was previously shown to lead to high-level constitutive activation of the $P_{R}$ and $P_{H}$ promoters (Arthur et al., 1997).

As expected, introduction of plasmid pAT392 $\left(P_{2}\right)$ into BM4332( $\left.P_{R} v a n R P_{H} v a n H A X\right)$ did not modify the regulation of $\operatorname{vanX}$ (Table 4). Production of VanS in BM4332 $\left(P_{R}\right.$ vanR $P_{H}$ van $\left.H A X\right) / \mathrm{pAT} 628\left(P_{2}\right.$ vanS $)$ restored inducible expression of the resistance genes (Table 4). Thus, VanS acted as a phosphatase under non-inducing conditions and prevented activation of $\mathrm{VanR}$ by the heterologous kinase (Fig. 2b). The negative control mediated by VanS was supressed by glycopeptides and reduced by moenomycin, leading to induction by these antibiotics (Table 4). This observation indicates that the phosphatase activity of VanS was inhibited by these antibiotics (Fig. 2b). VanS may act as a kinase under inducing conditions but this activity could not be detected since activation of VanR by cross-talk leads to transcription of $\operatorname{van} X$ at its maximum level as previously described (Arthur et al., 1997). Production of $\mathrm{VanSH}_{164} \mathrm{Q}$ in $\mathrm{BM} 4332\left(P_{R}\right.$ vanR $P_{H}$ van $\left.H A X\right) / \mathrm{pAT} 629$ $\left(P_{2} v a n S \mathrm{H} 164 \mathrm{Q}\right)$ prevented expression of vanX under all growth conditions (Table 4). Thus, $\mathrm{VanSH}_{164} \mathrm{Q}$ acted as a phosphatase and this activity was not modulated by glycopeptides or moenomycin (Fig. 2b). This observation suggests that the phosphatase activity of VanS

\section{Table 3. Control of $\operatorname{Van} R_{B}$ by various sensors}

Results are expressed as $\operatorname{VanX}_{\mathrm{B}}$ activity under the inducing conditions indicated. Data are means \pm SD obtained from a minimum of three independent extracts.

\begin{tabular}{|c|c|c|c|c|c|}
\hline \multirow[t]{2}{*}{ Strain } & \multirow[t]{2}{*}{ Van sensor } & \multicolumn{4}{|c|}{$\operatorname{Van} \mathrm{X}_{\mathrm{B}}$ activity $\left(\mathrm{nmol} \mathrm{min}^{-1} \mathrm{mg}^{-1}\right.$ ) } \\
\hline & & Uninduced & $\begin{array}{c}\text { Vancomycin } \\
\left(8 \mu \mathrm{g} \mathrm{ml}^{-1}\right)\end{array}$ & $\begin{array}{r}\text { Teicoplanin } \\
\left(0.5 \mu \mathrm{g} \mathrm{ml}^{-1}\right)\end{array}$ & $\begin{array}{l}\text { Moenomycin } \\
\left(0.04 \mu \mathrm{g} \mathrm{ml}^{-1}\right)\end{array}$ \\
\hline BM4399 & None & $21 \pm 4$ & $140 \pm 28$ & $270 \pm 120$ & $40 \pm 13$ \\
\hline BM4396 & $\operatorname{VanS}_{\mathrm{B}}$ & $3 \pm 1$ & $270 \pm 63$ & $5 \pm 2$ & $1 \pm 0$ \\
\hline BM4406 & $\operatorname{VanS}_{\mathrm{B}} \mathrm{H}_{233} \mathrm{Q}$ & $1 \pm 0$ & $82 \pm 9^{*}$ & $2 \pm 0$ & $1 \pm 0$ \\
\hline BM4407 & VanS & $470 \pm 130$ & $640 \pm 74$ & $610 \pm 130$ & $170 \pm 54$ \\
\hline BM4408 & $\operatorname{VanSH}_{164} \mathrm{Q}$ & $28 \pm 12$ & $110 \pm 72$ & $130 \pm 17$ & $19 \pm 7$ \\
\hline
\end{tabular}

"Induction was performed with $4 \mu \mathrm{g}$ vancomycin $\mathrm{ml}^{-1}$ since BM4406 does not grow in the presence of

$8 \mu \mathrm{g}$ vancomycin $\mathrm{ml}^{-1}$. 
(a) Activation of $\operatorname{VanR}_{B}$ and $\operatorname{VanR}$ by host kinase(s)

$\operatorname{VanR}_{B}$

Inducible by

$\mathrm{Vm}$, Te and Mo

Clonal variation under non-inducing conditions

\section{VanR}

Constitutive (inducible by

$\mathrm{Vm}, \mathrm{Te}$ and $\mathrm{Mo}$ if $P_{H}$ is present on a multicopy plasmid)

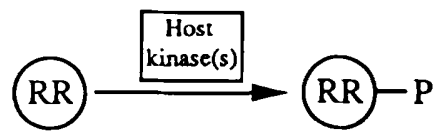

(b) Phosphatase activity of Van sensors

$\begin{array}{lll} & \operatorname{VanR}_{B} & \text { VanR } \\ \text { VanS }_{B} & \text { Inhibited by } \mathrm{Vm} & \text { Not active } \\ \operatorname{VanS}_{\mathrm{B}} \mathrm{H}_{233} \mathrm{Q} & \text { Inhibited by } \mathrm{Vm} & \text { Not active } \\ \text { VanS } & \text { Not active } & \text { Inhibited by Vm, Te and Mo } \\ \text { VanSH }_{164} \mathrm{Q} & \text { Not active } & \text { Active in all conditions }\end{array}$

(c) Kinase activity of Van sensors

$\begin{array}{llll}V_{\text {anS }} & \text { VanR }_{\mathbf{B}} & \text { VanR } \\ \text { VanS } & \begin{array}{l}\text { Stimulated by } V m \\ \text { Active in all }\end{array} & \begin{array}{l}\text { Not detectable } \\ \text { Not detectable }\end{array}\end{array}$

(d) Titration of VanR-phosphate by $\boldsymbol{P}_{\boldsymbol{H}}$ present on a multicopy plasmid

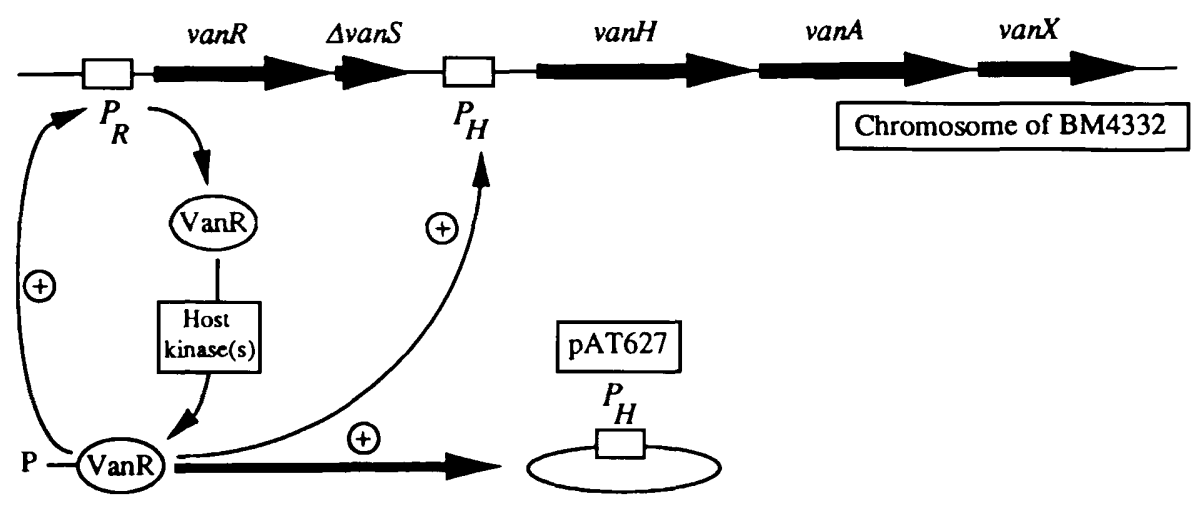

Fig. 2. Models for positive and negative controls of $\operatorname{Van} R$ and $\operatorname{Van}_{B}$ by various sensors. Phosphorylation and dephosphorylation of the response regulators are thought to be responsible for positive and negative control, respectively, of the transcription level of the resistance genes, although the kinase and phosphatase activities of the sensors were not determined. RR, $V a n R_{B}$ or $V a n R$ response regulator; $P$, phosphate. (a) Activation of $V_{a n} R_{B}$ and $V a n R$ by cross-talk. Previous analyses indicated that $\operatorname{VanR}$ and $V_{a n R_{B}}$ are activated by heterologous kinase(s) encoded by the host chromosome in vanS and vanS $S_{B}$ null mutants (see introduction). This mode of $V_{a n R_{B}}$ regulation leads to clonal variation under non-inducing conditions and to induction by vancomycin $(\mathrm{Vm})$, teicoplanin ( $\mathrm{Te}$ ) and moenomycin (Mo). VanR is constitutively activated by cross-talk in vans null mutants of wild-type VanA strains. However, cross-talk leads to induction by $\mathrm{Vm}, \mathrm{Te}$ and $\mathrm{Mo}$ if the $P_{H}$ promoter is carried by a multicopy plasmid (see below, Fig. 2d). (b) Phosphatase activity of $V_{a n S} S_{B}$ and VanS. The Van sensors were considered to act as phosphatases if the levels of vanX and van $X_{B}$ expression were significantly reduced in comparison to those in isogenic vans or van $S_{B}$ null mutants grown in the same conditions. According to this criterion, $\operatorname{VanS}_{B}$ and $V_{a n} S_{B} H_{233} Q$ dephosphorylated $V_{a n n} R_{B}$ and the phosphatase activity of both sensors was inhibited if medium contained $\mathrm{Vm}$. Vans and $\mathrm{VanSH}_{164} \mathrm{Q}$ dephosphorylated the cognate response regulator VanR. Inhibition of the phosphatase activity by $\mathrm{Vm}$, Te and Mo was only detected for the wild-type VanS sensor. $\operatorname{VanR}_{B}$ and $\operatorname{VanR}$ were not dephosphorylated by the heterologous sensors VanS and $\operatorname{VanS}_{B}$, respectively. (c) Kinase activity of $V_{a n} S_{B}$ and VanS. The Van sensors were considered to act as kinases if the levels of expression of van $X$ and $\operatorname{van}_{B}$ were increased in comparison to those in isogenic vans or vanS $S_{B}$ null mutants grown in the same conditions. According to this criterion, $\operatorname{VanR}_{\mathrm{B}}$ was activated (phosphorylated) by $\mathrm{VanS}_{\mathrm{B}}$ in the presence of $\mathrm{Vm}$ and by $\mathrm{VanS}$ in all conditions. Phosphorylation of VanR by $V_{a n S}$ or VanS could not be detected in the expression systems studied since activation of VanR by cross-talk led to transcription of vanX at its maximum level. (d) Model for regulation of vanX in 
Table 4. Activation of VanR in derivatives of $B M 4332\left(P_{R}\right.$ vanR $P_{H}$ vanHAX $)$ harbouring various plasmids

Results are expressed as VanX activity under the inducing conditions indicated. Data are means $\pm S D$ obtained from a minimum of three independent extracts.

\begin{tabular}{|c|c|c|c|c|c|}
\hline \multirow[t]{2}{*}{ Plasmid } & \multirow[t]{2}{*}{ Characteristics } & \multicolumn{4}{|c|}{ VanX activity ( $\mathrm{nmol} \mathrm{min}^{-1} \mathrm{mg}^{-1}$ ) } \\
\hline & & Uninduced & $\begin{array}{c}\text { Vancomycin } \\
\left(1 \mu \mathrm{g} \mathrm{ml}^{-1}\right)\end{array}$ & $\begin{array}{l}\text { Teicoplanin } \\
\left(0.5 \mu \mathrm{g} \mathrm{ml}^{-1}\right)\end{array}$ & $\begin{array}{l}\text { Moenomycin } \\
\left(0.05 \mu \mathrm{g} \mathrm{ml}^{-1}\right)\end{array}$ \\
\hline None & & $370 \pm 50$ & $410 \pm 27$ & $260 \pm 27$ & $100 \pm 20$ \\
\hline pAT392 & $P_{2}^{*}$ & $290 \pm 40$ & $250 \pm 21$ & $280 \pm 27$ & $98 \pm 18$ \\
\hline pAT628 & $P_{2}$ vanS & $5 \pm 1$ & $190 \pm 31$ & $280 \pm 55$ & $18 \pm 4$ \\
\hline pAT629 & $P_{2} \operatorname{vanSH}_{164} \mathrm{Q}$ & $2 \pm 1$ & $3 \pm 1$ & $4 \pm 3$ & $5 \pm 3$ \\
\hline pAT631 & $P_{2} \operatorname{vanS}_{B}$ & $320 \pm 10$ & $330 \pm 23$ & $280 \pm 23$ & $240 \pm 97$ \\
\hline pAT630 & $P_{2}$ vanS $_{B} \mathrm{H}_{233} \mathrm{Q}$ & $390 \pm 43$ & $380 \pm 28$ & $350 \pm 42$ & $330 \pm 14$ \\
\hline pAT627 & $P_{H}$ & $4 \pm 1$ & $67 \pm 34$ & $130 \pm 41$ & $32 \pm 4$ \\
\hline pAT626 & $P_{R}$ & $330 \pm 11$ & $320 \pm 23$ & $250 \pm 8$ & $130 \pm 19$ \\
\hline
\end{tabular}

"The $P_{2}$ promoter is constitutive and originates from the aphA-3 kanamycin resistance gene of enterococcal plasmid pJH1 (Trieu-Cuot et al., 1985; Arthur et al., 1997).

cannot be regulated independently from the reaction of autophosphorylation at $\mathrm{H}_{164}$. Alternatively, the $\mathrm{H}_{164} \mathrm{Q}$ substitution may have indirectly impaired signal transduction.

\section{Cross-talk between the VanRS and $\operatorname{Van}_{B} S_{B}$ systems}

Production of $\operatorname{VanS}_{\mathrm{B}}$ or $\mathrm{VanS}_{\mathrm{B}} \mathrm{H}_{233} \mathrm{Q}$ did not modify expression of $\operatorname{vanX}$ in $\mathrm{BM} 4332\left(P_{R}\right.$ vanR $P_{H}$ van $\left.H A X\right)$ (Table 4). Thus, $\operatorname{VanS}_{\mathrm{B}}$ did not prevent activation of VanR by the heterologous kinase, indicating that the sensor of the vanB cluster was unable to dephosphorylate the heterologous $\mathrm{VanR}$ response regulator encoded by the vanA cluster (Fig. 2b). Activation of VanR by VanS $S_{B}$ could not be tested in this system since vanX was constitutively expressed at a high level in the vanS null mutant BM4332 $\left(P_{R}\right.$ vanR $_{H}$ van $\left.H A X\right)$ (Table 4 and Fig. 2c). In E. coli, deletion of the phoBR, creBC and ackA-pta loci prevents activation of VanR by cross-talk (Silva et al., 1998). However, activation of VanR by VanS $_{B}$ could not be tested since VanS $_{B}$ was locked in a phosphatase state in this host. In addition, induction by glycopeptides could not be studied since the drugs do not penetrate the E. coli outer membrane.

In comparison to the van $S_{B}$ null mutant BM4399, VanX $X_{B}$ activity was higher in BM4407, which contained
pAT628 $\left(P_{2}\right.$ vanS $)$, suggesting that $\mathrm{VanS}$ activated $\mathrm{VanR}_{\mathrm{B}}$ (Table 3). VanS stimulated expression of van $X_{B}$ under all growth conditions. VanS and the heterologous kinase were previously shown to be stimulated by the same antibiotics and to mediate low-level expression of the resistance genes in the absence of inducers (Table 1; Baptista et al., 1999). Thus, the two kinases may contribute to activation of $\mathrm{VanR}_{B}$ in $\mathrm{BM} 4407$ (Fig. 2c). As expected, production of $\mathrm{VanSH}_{164} \mathrm{Q}$ did not increase expression of $\operatorname{van} X_{B}$ (BM4408 in Table 3). Previous attempts to detect activation of $\operatorname{VanR}_{B}$ by $\operatorname{VanS}$ in $E$. coli were unsuccessful since $\operatorname{VanR}_{\mathrm{B}}$ was constitutively activated by cross-talk in spite of deletions of the phoBR, creBC and ackA-pta loci (Silva et al., 1998). The VanS sensor was locked in an activator (kinase) state in this host. In contrast, VanS displayed phosphatase activity in E. faecalis in the absence of glycopeptides in the growth medium (Table 3 and Fig. 2b).

\section{Activation of VanR in derivatives of BM4332 harbouring the $P_{R}$ and $P_{H}$ promoters on multicopy plasmids}

Introduction of the multicopy plasmid pAT627 containing $P_{H}$ in $\mathrm{BM} 4332\left(P_{R}\right.$ vanR $P_{H}$ van $\left.H A X\right)$ prevented expression of the chromosomal copy of vanX under non-inducing conditions (Table 4). Synthesis of VanX

BM4332 $\left(P_{R}\right.$ vanR $P_{H}$ vanHAX)/pAT627 $\left(P_{H}\right)$. VanR stimulates its own synthesis since binding of the phosphorylated form of VanR (P-VanR) to $P_{R}$ activates transcription of vanR. In BM4332 $\left(P_{R}\right.$ vanR $P_{H}$ van $\left.H A X\right)$, the amplification loop compensates for inefficient phosphorylation of VanR in the absence of a stimulus for the host kinase(s). However, the amplification loop does not function in BM4332 $\left(P_{R} v a n R P_{H}\right.$ vanHAX)/pAT627 $\left(P_{H}\right)$ since P-VanR preferentially binds to the high-affinity $P_{H}$ promoter located on plasmid pAT627. Expression of vanX is inducible by glycopeptides and moenomycin since stimulation of the host kinase by these antibiotics is required for efficient phosphorylation of VanR and synthesis of this protein. 
Table 5. trans-activation of the $P_{H}$ and $P_{R}$ promoters by VanR in various hosts

Results are expressed as chloramphenicol acetyltransferase activity under the inducing conditions indicated. Data are means \pm SD obtained from a minimum of three independent extracts.

\begin{tabular}{|c|c|c|c|c|c|}
\hline \multirow[t]{2}{*}{ Host } & \multirow[t]{2}{*}{ Plasmid } & \multicolumn{4}{|c|}{$\begin{array}{l}\text { Chloramphenicol acetyltransferase activity } \\
\qquad\left(\mathrm{nmol} \mathrm{min}^{-1} \mathrm{mg}^{-1}\right)\end{array}$} \\
\hline & & Uninduced & $\begin{array}{l}\text { Vancomycin } \\
\left(0.5 \mu \mathrm{g} \mathrm{ml}^{-1}\right)\end{array}$ & $\begin{array}{c}\text { Teicoplanin } \\
\left(0.25 \mu \mathrm{g} \mathrm{ml}^{-1}\right)\end{array}$ & $\begin{array}{l}\text { Moenomycin } \\
\left(0.05 \mu \mathrm{g} \mathrm{ml}^{-1}\right)\end{array}$ \\
\hline $\mathrm{JH} 2-2$ & $\begin{array}{l}\text { pAT78 }(\text { cat }) \\
\left.\text { pAT418(P } P_{h} \text { cat }\right) \\
\text { pAT90 }\left(P_{H} \text { cat }\right)\end{array}$ & $\begin{array}{l}230 \pm 110 \\
830 \pm 520 \\
150 \pm 49\end{array}$ & $\begin{array}{l}220 \pm 79 \\
380 \pm 160 \\
150 \pm 22\end{array}$ & $\begin{array}{l}310 \pm 130 \\
550 \pm 340 \\
360 \pm 170\end{array}$ & $\begin{array}{l}160 \pm 170 \\
500 \pm 13 \\
430 \pm 120\end{array}$ \\
\hline $\mathrm{BM} 4311\left(P_{n} t^{\prime} a n R S\right)$ & $\begin{array}{l}\text { pAT78 }(\text { cat }) \\
\left.\text { pAT418(P } P_{R} \text { cat }\right) \\
\text { pAT } 90\left(P_{H} \text { cat }\right)\end{array}$ & $\begin{array}{l}450 \pm 240 \\
370 \pm 97 \\
160 \pm 95\end{array}$ & $\begin{array}{c}290 \pm 70 \\
3700 \pm 1000 \\
2000 \pm 620\end{array}$ & $\begin{array}{c}230 \pm 120 \\
4300 \pm 1400 \\
7900 \pm 2600\end{array}$ & $\begin{array}{r}560 \pm 320 \\
1600 \pm 330 \\
2000 \pm 480\end{array}$ \\
\hline $\mathrm{BM} 4312\left(P_{2}\right.$ tan $\left.R\right)$ & $\begin{array}{l}\text { pAT78 }(\text { cat }) \\
\left.\text { pAT418(P } P_{R} \text { cat }\right) \\
\text { pAT90 }\left(P_{H} \text { cat }\right)\end{array}$ & $\begin{array}{c}120 \pm 66 \\
4400 \pm 1200 \\
10000 \pm 1600\end{array}$ & $\begin{array}{c}100 \pm 19 \\
5300 \pm 1500 \\
9900 \pm 2700\end{array}$ & $\begin{array}{c}29 \pm 140 \\
10000 \pm 1300 \\
15000 \pm 560\end{array}$ & $\begin{array}{c}89 \pm 30 \\
9300 \pm 3000 \\
22000 \pm 5900\end{array}$ \\
\hline $\mathrm{BM} 4375\left(P_{R} \operatorname{van} R\right)$ & $\begin{array}{l}\text { pAT78 }(\text { cat }) \\
\left.\text { pAT418( } P_{R} c a t\right) \\
\text { pAT90 }\left(P_{H} c a t\right)\end{array}$ & $\begin{array}{c}250 \pm 42 \\
9200 \pm 1400 \\
790 \pm 240\end{array}$ & $\begin{array}{c}430 \pm 330 \\
10000 \pm 1800 \\
1800 \pm 480\end{array}$ & $\begin{array}{c}790 \pm 320 \\
8900 \pm 880 \\
3600 \pm 1000\end{array}$ & $\begin{array}{c}520 \pm 62 \\
4900 \pm 640 \\
5100 \pm 1000\end{array}$ \\
\hline
\end{tabular}

was inducible by vancomycin, teicoplanin and moenomycin, indicating that stimulation of the heterologous kinase by these antibiotics was required for activation of the resistance genes located in the chromosome. Notably, induction occurred with the same antibiotics in van $S_{B}$ null mutants (Table 1), raising the possibility that $\operatorname{VanR}$ and $\operatorname{VanR}_{\mathrm{B}}$ may be activated by the same host kinase. The $P_{R}$ promoter of plasmid pAT626 had no effect on the regulation of the vanX gene of BM4332 $\left(P_{R}\right.$ vanR $_{H}$ van $\left.H A X\right)$.

\section{trans-activation of the $P_{R}$ and $P_{H}$ promoters}

We previously compared the regulation of the $P_{R}$ and $P_{H}$ promoters in E. faecalis $\mathrm{JH} 2-2$ and derivatives harbouring a chromosomal copy of vanR and vanS under the control of $P_{R}(\mathrm{BM} 4311)$ or of $v a n R$ alone under the control of the heterologous promoter $P_{2}$ (BM4312) (Arthur et al., 1992, 1997). In this study, we extended this analysis to a novel host, BM4375(P $\left.P_{R} v a n R\right)$, that contained a chromosomal copy of vanR under the control of $P_{R}$. Plasmids pAT418 $\left(P_{R} c a t\right)$ and pAT90 $\left(P_{H}\right.$ cat $)$ containing a cat reporter gene transcriptionally fused to $P_{R}$ and $P_{H}$ were introduced into these three hosts. The $P_{H}$ and $P_{R}$ promoters were not active in $\mathrm{JH} 2-2$ and inducible by glycopeptides and moenomycin in BM4311 $\left(P_{R} v a n R S\right)$ (Table 5). The $P_{H}$ promoter of pAT90 $\left(P_{H}\right.$ cat $)$ was constitutive in BM4312 $\left(P_{2}\right.$ vanR $)$ and inducible by glycopeptides and moenomycin in BM4375( $P_{R}$ vanR $)$. Thus, activation of VanR required stimulation of the heterologous kinase by glycopeptides or moenomycin if $P_{H}$ was present on a multicopy plasmid and $v a n R$ was expressed under the control of $P_{R}$ (Fig. 2a). In contrast, expression of vanR under the control of $P_{2}$ in BM4312 $\left(P_{2}\right.$ vanR $)$ or of $P_{R}$ in BM4375 $\left(P_{R}\right.$ vanR $)$ led to constitutive activation of the $P_{R}$ promoter of pAT418 $\left(P_{R} c a t\right)$.

\section{A model for inducible expression of the resistance genes in vanS null mutants harbouring $P_{H}$ on a multicopy plasmid}

Comparison of wild-type and vanS null mutants indicated that activation of VanR by cross-talk is very efficient since production of $\mathrm{VanS}$ does not increase transcription initiation at $P_{R}$ and $P_{H}$ (Arthur et al., 1997). This observation is surprising since phosphorylation of response regulators by heterologous kinases is not expected to be efficient (Fisher et al., 1995; Hoch \& Silhavy, 1995). Two factors were thought to contribute to the accumulation of the phosphorylated form of VanR (VanR-P) in the absence of VanS (Arthur et al., 1997). First, hydrolysis of phospho-VanR in the absence of VanS is remarkably slow in vitro $\left(\mathrm{t}_{1 / 2}=10-12 \mathrm{~h}\right)$ (Wright et al., 1993). Second, the amplification loop resulting from activation of $P_{R}$ by VanR (Fig. 2d) may compensate for inefficient phosphorylation of the regulator (Arthur et al., 1997). However, activation of VanR required stimulation of the heterologous kinase by glycopeptides or moenomycin in BM4332 $\left(P_{R}\right.$ vanR $P_{H}$ vanHAX)/pAT627 $\left(P_{H}\right)$ and in BM4375 $\left(P_{R}\right.$ vanR $) /$ pAT90 $\left(P_{H}\right.$ cat) (Tables 4 and 5 ). We propose that $P_{H}$, present on multicopy plasmids in these strains, competed with the chromosomal copy of $P_{R}$ for limiting amounts of VanR-P in the absence of a stimulus for the heterologous kinase (Fig. 2d). If VanR-P preferentially 
binds to the plasmid-borne $P_{H}$ promoter, the concentration of VanR-P may not be sufficient for activation of the chromosomal $P_{R}$ promoter and synthesis of VanR in the absence of induction. In agreement with this model, VanR-P displays a 40-fold higher affinity for $P_{H}$ than for $P_{R}$ (Holman et al., 1994). Activation of VanR in BM4375 $\left(P_{R}\right.$ vanR) was not affected by the presence of $P_{R}$ on a multicopy plasmid (Table 5) indicating that the difference in the affinity of VanR-P for the two promoters was critical for the inducible phenotype. Inducible activation of VanR in the absence of VanS was only detected in strains harbouring $P_{R}$ in the chromosome and $P_{H}$ on a multicopy plasmid (Tables 4 and 5) (Arthur et al., 1997). Thus, the difference in the relative concentration of the two promoters was also critical. Finally, stimulation of the heterologous kinase was only required if $v a n R$ was expressed under the control of $P_{R}$ since the $P_{H}$ promoter of pAT90 $\left(P_{H} c a t\right)$ was inducible in BM4375(P $P_{R}$ vanR $)$ but constitutive in BM4312( $P_{2}$ van $\left.R\right)$ (Table 5).

\section{ACKNOWLEDGEMENTS}

This work was supported in part by a Bristol-Myers-Squibb Unrestricted Biomedical Research Grant in Infectious Diseases.

\section{REFERENCES}

Arthur, M., Molinas, C. \& Courvalin, P. (1992). The VanS-VanR two-component regulatory system controls synthesis of depsipeptide peptidoglycan precursors in Enterococcus faecium BM4147. J Bacteriol 174, 2582-2591.

Arthur, M., Depardieu, F., Snaith, H. A., Reynolds, P.E. \& Courvalin, P. (1994). Contribution of VanY D,D-carboxypeptidase to glycopeptide resistance in Enterococcus faecalis by hydrolysis of peptidoglycan precursors. Antimicrob Agents Chemother 38, 1899-1903.

Arthur, M., Depardieu, F., Reynolds, P. \& Courvalin, P. (1996a). Quantitative analysis of the metabolism of soluble cytoplasmic peptidoglycan precursors of glycopeptide-resistant enterococci. Mol Microbiol 21, 33-44.

Arthur, M., Reynolds, P. \& Courvalin, P. (1996b). Glycopeptide resistance in enterococci. Trends Microbiol 4, 401-407.

Arthur, M., Depardieu, F., Gerbaud, G., Galimand, M., Leclercq, R. \& Courvalin, P. (1997). The VanS sensor negatively controls VanR-mediated transcriptional activation of glycopeptide resistance genes of $\mathrm{Tn} 1546$ and related elements in the absence of induction. J Bacteriol 179, 97-106.

Arthur, M., Depardieu, F., Cabanié, L., Reynolds, P. \& Courvalin, $P$. (1998). Requirement of the VanY and VanX D,D-peptidases for glycopeptide resistance in enterococci. Mol Microbiol 30 , 819-830.

Ausubel, F. M., Brent, R., Kingston, R. E., Moore, D. D., Seidman, J. G., Smith, J. A. \& Struhl, K. (1987). Current Protocols in Molecular Biology. New York: Wiley.

Baptista, M., Depardieu, F., Courvalin, P. \& Arthur, M. (1996). Specificity of induction of glycopeptide resistance genes in Enterococcus faecalis. Antimicrob Agents Chemother 40, 2291-2295.

Baptista, M., Depardieu, F., Reynolds, P., Courvalin, P. \& Arthur, M. (1997). Mutations leading to increased levels of resistance to glycopeptide antibiotics in VanB-type enterococci. Mol Microbiol 25, 93-105.

Baptista, M., Rodrigues, P., Depardieu, F., Courvalin, P. \& Arthur, M. (1999). Single cell analysis of glycopeptide resistance gene expression in teicoplanin-resistant mutants of VanB-type Enterococcus faecalis. Mol Microbiol 32, 17-28.

Bugg, T. D. H., Wright, G. D., Dutka-Malen, S., Arthur, M., Courvalin, P. \& Walsh, C. T. (1991). Molecular hasis for vancomycin resistance in Enterococcus faecium BM4147: biosynthesis of a depsipeptide peptidoglycan precursor by vancomycin resistance proteins $\mathrm{VanH}$ and VanA. Biochemistry 30, 10408-10415.

Courvalin, P. \& Carlier, C. (1986). Transposable multiple antibiotic resistance in Streptococcus pneumoniae. Mol Gen Genet 205, 291-297.

Cruz-Rodz, A. L. \& Gilmore, M. S. (1990). High efficiency introduction of plasmid DNA into glycine treated Enterococcus faecalis by electroporation. Mol Gen Genet 224, 152-154.

Evers, S. \& Courvalin, P. (1996). Regulation of VanB-type vancomycin resistance gene expression by the $\operatorname{VanS}_{B}-V_{a n R} t_{B}$ wocomponent regulatory system in Enterococcus faecalis V583. J Bacteriol 178, 1302-1309.

Fisher, S., Jiang, W., Wanner, B. \& Walsh, C. (1995). Cross-talk between the histidine protein kinase $\mathrm{VanS}$ and the response regulator PhoB. J Biol Chem 270, 23143-23149.

Haldimann, A., Fisher, S. L., Daniels, L. L., Walsh, C. T. \& Wanner, B. L. (1997). Transcriptional regulation of the Enterococcus faecium BM 4147 vancomycin resistance gene cluster by the VanSVanR two-component regulatory system in Escherichia coli K-12. J Bacteriol 179, 5903-5913.

Handwerger, S. \& Kolokathis, A. (1990). Induction of vancomycin resistance in Enterococcus faecium by inhibition of transglycosylation. FEMS Microbiol Lett 70, 167-170.

Hoch, J.A. \& Silhavy, T. J. (1995). Two-component Signal Transduction. Washington, DC: American Society for Microbiology.

Holman, T. R., Wu, Z., Wanner, B. L. \& Walsh, C. T. (1994). Identification of the DNA-binding site for the phosphorylated VanR protein required for vancomycin resistance in Enterococcus faecium. Biochemistry 33, 4625-4631.

Hsing. W. \& Silhavy, T. J. (1997). Function of conserved histidine243 in phosphatase activity of EnvZ, the sensor for porin osmoregulation in Escherichia coli. J Bacteriol 179, 3729-3735.

Jacob, A. E. \& Hobbs, S. J. (1974). Conjugal transfer of plasmidborne multiple antibiotic resistance in Streptococcus faecalis var. zymogenes. J Bacteriol 117, 360-372.

Silva, J. C., Haldimann, A., Prahalad, M. K., Walsh, C. T. \& Wanner, B. L. (1998). In vivo characterization of the type A and B vancomycin-resistant enterococci (VRE) VanRS two-component systems in Escherichia coli: a nonpathogenic model for studying the VRE signal transduction pathways. Proc Natl Acad Sci USA 95, 11951-11956.

Trieu-Cuot، P., Klier, A. \& Courvalin, P. (1985). DNA sequences specifying the transcription of the streptococcal kanamycin resistance gene in Escherichia coli and in Bacillus subtilis. Mol Gen Genet 198, 348-352.

Trieu-Cuot, P., Carlier, C., Poyart-Salmeron, C. \& Courvalin, P. (1990). A pair of mobilizable shuttle vectors conferring resistance to spectinomycin for molecular cloning in Escherichia coli and in Gram-positive bacteria. Nucleic Acids Res 18, 4296.

Trieu-Cuot, P., Carlier, C., Poyart-Salmeron, C. \& Courvalin, P. (1991). An integrative vector exploiting the transposition proper- 
ties of $\operatorname{Tn} 1545$ for insertional mutagenesis and cloning of genes from gram-positive bacteria. Gene 106, 21-27.

Walsh, C., Fisher, S., Park, I.-S., Prahalad, M. \& Wu, Z. (1996). Bacterial resistance to vancomycin: five genes and one missing hydrogen bond tell the story. Chem Biol 3, 21-28.

Wright, G. D., Holman, T. R. \& Walsh, C. T. (1993). Purification and characterization of VanR and the cytosolic domain of VanS: a two-component regulatory system required for vancomycin resistance in Enterococcus faecium BM4147. Biochemistry 32, 5057-5063.

Received 12 January 1999; revised 19 April 1999; accepted 22 April 1999. 